\title{
Reform and Practice of Curriculum System Based on Applied Innovative Talents Training
}

\author{
Xuefei $L v^{1, a}$ and Shukun Gan ${ }^{1, b^{*}}$ \\ ${ }^{1}$ College of Mechanical and Electrical Engineering, Jilin Institute of Chemical Technology, Jilin \\ 132022, China \\ a108825021@qq.com, b49141544@qq.com
} Keywords: Applied innovative talents; OBE; Energy and power engineering; Curriculum system;
Curriculum system reform

\begin{abstract}
In order to strengthen the cultivation of applied innovative talents, based on the experience of energy and power engineering, combining talent demand analysis and OBE engineering education training concepts, through the systematic optimization and integration of the professional curriculum system, the teaching methods and means are reformed , and put into practice. The results show that the reform practice has effectively improved the students' comprehensive professional quality and ability, and the student employment rate and social adaptability have been significantly improved, and the training goal of applied innovative talents has been achieved. The teaching reform methods and concepts adopted in this study have important theoretical guiding significance and extensive practical promotion value.
\end{abstract}

\section{Introduction}

Establishing an innovative country is a major strategy for achieving national rejuvenation, training applied innovative talents is an important idea of national education planning. Global economic integration has made the competition between countries more fierce. Innovation and mastery of core technologies have become the key to the survival of enterprises. Therefore, cultivating high-quality applied innovative talents that meet the requirements of economic development and social needs is an important mission of colleges and universities [1]. This paper combines the characteristics of engineering application-oriented innovative talent training. Summarize the school's experience in energy and power engineering, through the reform of the talent training model, optimizing and perfecting the professional curriculum system, updating the curriculum content, and reforming the teaching methods have explored effective methods and approaches for achieving the training objectives of applied innovative talents.

\section{Necessity of Training Mode Reform for Applied Innovation Talent}

Applied innovation talents are those who can closely relate to the social environment, integrate and innovate multidisciplinary knowledge, and be able to creatively solve practical engineering problems and systemic engineering problems.

As a base for talent training, colleges and universities are responsible for cultivating engineering-based application-oriented innovative talents. How to improve the quality of engineering professional and technical personnel training, cultivate high-quality engineering application-oriented innovative talents that meet the needs of society. It is of great significance to improve the overall quality of China's higher engineering education and promote local economic and social development. Reform the talent training model, and continuously update the professional knowledge content through the optimization and integration of the curriculum system. It is the main way to achieve the training goal of innovative talents in college engineering quality education [2-5]

\section{Top Level Design of Curriculum System}

The construction of the curriculum system is an important part of the talent training model.In the 
process of formulating talent training programs, our school requires that we fully absorb the advanced educational concepts and methods of universities at home and abroad. Especially, Washington Agreement in national engineering education certification is successful experience. In accordance with the concept of Outcomes-based Education (OBE), the science design curriculum system. According to the status of the course in the cultivation of talents, a modular curriculum system is established to optimize the combination of courses. The course architecture is shown in Fig. 1.

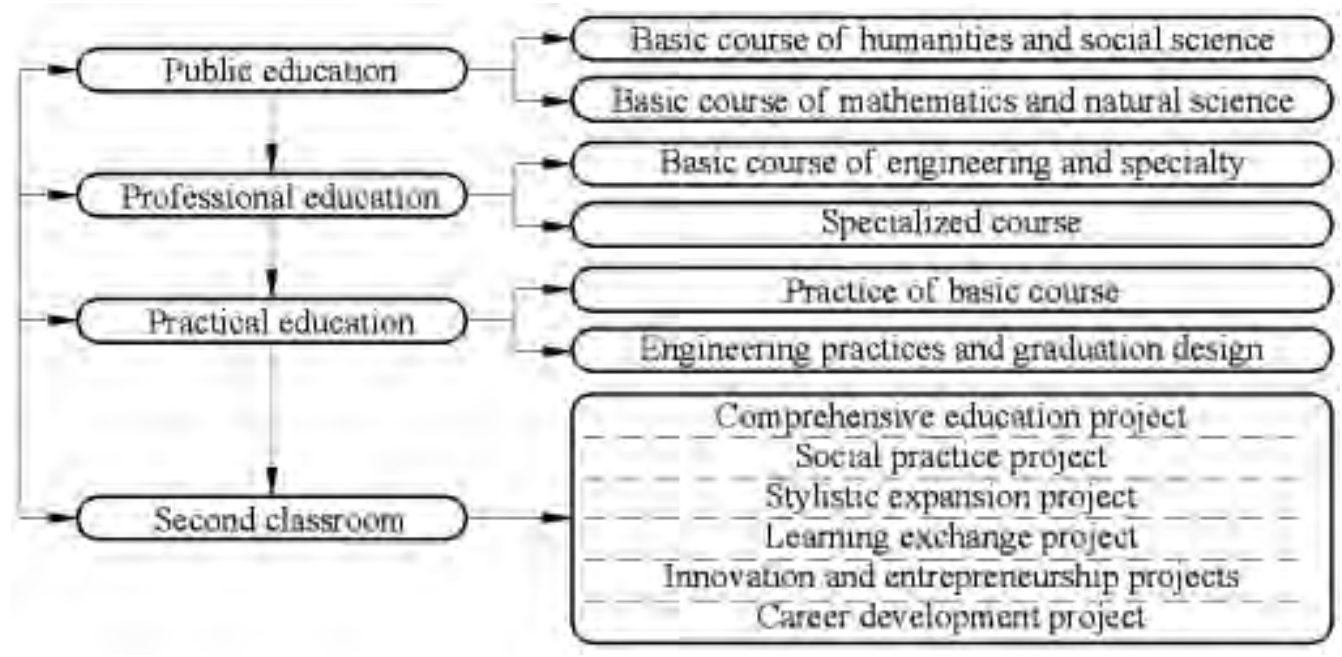

Figure 1. Course architecture diagram

The engineering major requires that the total credits be controlled within 170 credits. Among them, humanities and social science courses account for at least $15 \%$, mathematics and natural science courses at least $15 \%$, engineering majors and professional courses at least $30 \%$, engineering practice and graduation design (thesis) at least $25 \%$, the second class is at least 4 credits.

\section{Optimization and Practice Based on Professional Curriculum System}

Our school's energy and power engineering profession has always been guided by industry development and social needs during the years of running schools. The OBE concept is used to guide the reform of engineering quality education and to cultivate applied talents that meet the needs of society. The profession has long insisted that all members participate in the teaching research and teaching reform, combining the social needs and the long-term development strategy of talents and the reality of our school. Formed and perfected the professional school-running thinking of cultivating comprehensive application-oriented innovative talents suitable for social needs.

Optimized Integration of Professional Courses. In combination with the school's energy and power engineering professional experience in the process of talent revision, the professional curriculum has been rationally optimized and integrated, as shown in Fig.2.The five-door 168-time professional theory course was optimized and integrated into four doors and 120 hours.

At the same time, through the establishment of professional courses to cultivate students' awareness of innovation and entrepreneurship and internationalization capabilities. For example, the academic leaders ,the external enterprise engineering and technical personnel teach the professional introductions, frontier lectures, and introduction to professional safety. Improve students' humanities, engineering, professional and innovative entrepreneurial awareness, the inter-professional courses or professional elective courses modules can be set up to meet and promote students' individualized learning and development.

Strengthening of Practice. Through practical teaching, cultivate application-oriented innovative talents that are more suitable for social needs [3].In the process of revision of the talent training program, the energy and power engineering major of our school pays attention to strengthening the 
cultivation of students' practical ability, engineering quality and innovative ability. Continuous optimization and integration of professional practice, curriculum design, internship, graduation design, etc. Appropriately increase the proportion and adjust the content to provide a strong guarantee for cultivating students' innovative practical ability. In the new version of the talent training program, the total credits in the practice teaching link have reached $27.4 \%$, an increase of 8 credits, nearly 5 percentage points, as shown in Table 1 . [6,7]

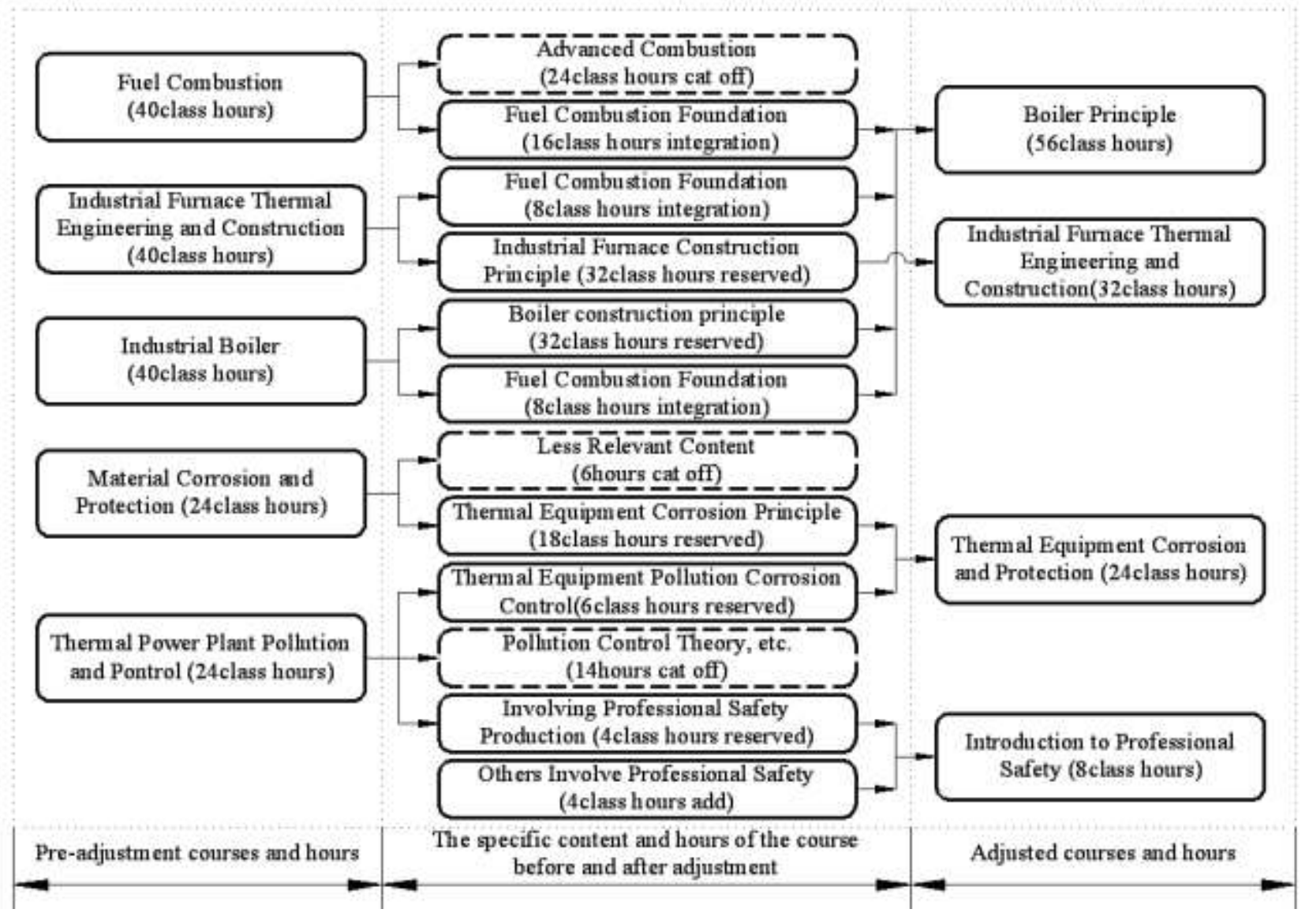

Figure 2. The comparison of optimization and integration

Table 1 Proportion of credits for practical teaching links

\begin{tabular}{cccc}
\hline reform & total credits & practical credits & Percentage of practice \\
\hline befor & 170 & 38.5 & $22.6 \%$ \\
after & 170 & 46.5 & $27.4 \%$ \\
\hline
\end{tabular}

Cultivation of Innovative Ability. Improve students' innovative ability and comprehensive practical quality by creating a multi-faceted research and practice training platform. Through the establishment of an innovation platform, students are encouraged to actively participate in extracurricular research activities, subject lectures and other links, so that students learn to think deeply, connect theory with practice, solve problems on their own, and improve teamwork awareness [8].Encourage students to actively participate in the discipline competition through the second classroom to complete the curriculum and practice teaching links other than those specified in the training program.

Curriculum Construction and Teaching Method Reform. In the professional school process, combined with the OBE concept to build a professional curriculum and practical curriculum system, pay attention to the importance of curriculum construction in the process of talent cultivation. 
Adhere to the standards and requirements of quality courses and excellent courses to improve relevant teaching resources. Actively create professional excellent courses and quality courses, effectively improve the quality of teaching, and drive the construction and development of the entire profession. Strengthen the reform and practice of the teaching methods of the curriculum, actively reform the traditional teaching model, make full use of modern teaching methods, such as multimedia teaching, MOOC online teaching and virtual simulation teaching, etc. Innovate old teaching methods and teaching methods to better activate the classroom atmosphere. Engage students in teaching, strengthen classroom interaction, and improve teaching effectiveness. Innovative education teaching methods advocate heuristic, inquiry, discussion, and participatory teaching, and strive to explore diverse teaching methods [9-11].

\section{Teaching Reform Effectiveness}

With the continuous deepening of the teaching reform and practice of energy and power engineering in our school, the overall education strategy is clear, the development trend is good. The student's graduation design excellent rate, graduation rate, employment rate and counterpart rate have been significantly improved compared with the pre-reform, as shown in Table 2 . The students' ability to work and start businesses is growing, graduates are also very popular with employers. The reputation of social adaptability and social recognition is constantly improving. Achieved the training goal of applied innovative talents.

Table 2 Effect of teaching reform

\begin{tabular}{ccccc}
\hline \multirow{2}{*}{ reform grade } & \multicolumn{2}{c}{ before } & \multicolumn{2}{c}{ after } \\
& 2011 & 2012 & 2013 & 2014 \\
\hline graduation design excellent rate/[\%] & 29.63 & 25.64 & 57.27 & 59.18 \\
graduation rate/[\%] & 95.45 & 93.98 & 98.21 & 98.00 \\
employment rate/[\%] & 91.43 & 89.74 & 97.27 & 96.94 \\
counterpart employment rate/[\%] & 80.21 & 78.57 & 93.46 & 94.74 \\
\hline
\end{tabular}

\section{Conclusion}

Talent cultivation is a systematic project. Improving the application innovation and practical ability of engineering professionals is of great significance to the development of social economy. Only by clarifying the goal of talent training, through the practice of a series of talent training modes, such as curriculum system optimization and teaching method reform, the overall quality of students can be better improved. Consolidate the theoretical foundation, teach students in accordance with their aptitude. Effectively improve students' ability to innovate and practice, and achieve professional talent training goals, develop true application-oriented innovative talents for the society.

\section{References}

[1] Q.S.Zhou, H.W.Liu: Science and Technology Vision,(2016)No.14,p.192. (In Chinese)

[2] Z.G.Chen,X.H.Yang,J.R.Wu,B.C.Fu,Z.N.Xu and X.W.Zhang: Higher Engineering Education Research,(2012)No.01,p.75-80. (In Chinese)

[3] Z.Li: Chinese University Teaching, (2012)No.03,p12-14+56. (In Chinese)

[4] L.Zhang: Journal of Jilin Institute of Chemical Technology, (2016)No,12,p.42-44+48. (In Chinese)

[5] L.M.Wang: Experimental Technology and Management,(2014)No.8,p.19-21. (In Chinese)

[6] R.Q.Zhang: Curriculum education research, (2015)No.8,p.74-75. (In Chinese)

[7] L.M.Yao,W.H.Duan: Chinese university teaching, (2013)No.8,p.60-64. (In Chinese)

[8] S.S.Zhou: Technological Innovation(Higher Education Press,China 2002),p.55. (In Chinese)

[9] X.X.Zou: Research on the Construction of Innovative Talent Team in Innovative Cities(MS., 
Hefei University of Technology, China 2013),p.25. (In Chinese)

[10] H.S.Xiao,H.S.Chen and L.Chen: Human Resource Management, (2014)No.01,p.147-148. (In Chinese)

[11] Y.P.Sun,C.G.Sun; Journal of Jilin Institute of Chemical Technology, (2013)No12,p.88-90. (In Chinese) 